\title{
Ecology and distribution of
}

macroscopic algae communities in streams from the Basin of

Mexico

\section{creative} commons

Botanical Sciences

96 (1): 63-75, 2018

DOI: $10.17129 /$ botsci.1237

Received:

March 13th, 2017

Accepted:

June 20th, 2017

Associated Editor:

Juan Núñez Farfán
This is an open access article distributed under the terms of the Creative Commons Attribution License, which permits unrestricted use, distribution, and reproduction in any medium, provided the original author and source are credited.

\section{Posgrado en Ciencias}

Biológicas, Universidad Nacional Autónoma de México, Coyoacán, 04510. Ciudad de México, México.

2 Laboratorio Ecosistemas de Ribera, Facultad de Ciencias, Universidad Nacional Autónoma de México. Circuito exterior $\mathrm{s} / \mathrm{n}$. Ciudad Universitaria, Coyoacán. 04510. Ciudad de México, México.

* Corresponding author: rofr@ciencias.unam.mx
Rogelio RodríGueZ-Flores ${ }^{1,2 *}$ and JaVIer CARMONa-JiméneZ ${ }^{2}$

\section{Abstract}

Background: Several studies of lotic ecosystems have provided important ecological information on the influence of environmental heterogeneity on macroscopic algae composition.

Hypothesis: The highest species diversity will occur during the cold-dry season, correlated to low temperature and oligothrophic water, while the distribution of each species will be related to heterogeneity of habitat and its dispersal strategies.

Studied species: Twenty-two species of macroscopic algae of different Phyla (Chlorophyta, Cyanobacteria, Heterokontophyta and Rhodophyta).

Study site: The macroscopic algae composition was described for 35 permanent mountain streams in the Basin of Mexico from 2012 to 2015 .

Methods: Algae species, physico-chemical water conditions and microhabitat factors were recorded in situ at each contrasting season. The relationship between diversity and the environmental factors was statistically evaluated by Canonical Correspondence Analysis and a Spearman test.

Results: Macroscopic algae recorded had biological features and environmental abilities that separated them into two groups. The first included the most frequent and abundant species: Nostoc parmelioides, Placoma regularis, Prasiola mexicana and Vaucheria bursata. The second included species restricted to certain habitats: Draparnaldia mutabilis, Tetraspora gelatinosa, Batrachospermum gelatinosum and Paralemanea mexicana. Each Phyla responds differentially to the spatial heterogeneity of the streams, but the species does not change between contrasting seasons.

Conclusions: Local and spatial environmental variables explain differences in richness and distribution of species on the studied area; however, species composition does not vary widely among sampling sites. Cyanobacteria and Chlorophyta are more affected by local environmental variables, whereas Rhodophyta is more influenced by spatial variables.

Keywords: Aquatic communities, Basin of Mexico, macroscopic algae, mountain streams.

\section{Resumen}

Antecedentes: Diversos estudios de ecosistemas lóticos han aportado información ecológica importante sobre la influencia de la heterogeneidad ambiental en la composición de algas macroscópicas.

Hipótesis: La mayor diversidad se presentará durante la estación fría y estará relacionada con la baja temperatura y las condiciones oligotróficas del agua; mientras que la distribución de cada especie estará relacionada con la heterogeneidad del hábitat y las diversas estrategias de dispersión.

Especie en estudio: Veintidós especies de algas macroscópicas de diferentes Phyla (Chlorophyta, Cyanobacteria, Heterokontophyta y Rhodophyta).

Sitio de estudio: Fue estudiada la composición de algas macroscópicas en 35 ríos de montaña de la cuenca de México, entre 2012 y 2015.

Métodos: Las especies, las variables fisicoquímicas del agua y microambientales fueron registradas in situ durante las estaciones más contrastantes. La relación entre la diversidad y los factores ambientales fueron evaluados estadísticamente a través de un Análisis de Correspondencia Canónica y una prueba de Spearman.

Resultados: Las 22 especies de algas macroscópicas registradas presentaron características biológicas que permitieron separarlas en dos grandes grupos. El primero incluyó a las especies más frecuentes y abundantes: Nostoc parmelioides, Placoma regularis, Prasiola mexicana y Vaucheria bursata. El segundo incluyó a las especies de hábitat restringido: Draparnaldia mutabilis, Tetraspora gelatinosa, Mougeotia sp., Batrachospermum gelatinosum y Paralemanea mexicana. Cada Phyla responde diferencialmente a la heterogeneidad espacial de los ríos, pero las especies no cambian entre estaciones contrastantes.

Conclusiones: Las variables ambientales locales y espaciales explican diferencias en la riqueza y distribución de las especies en el área de estudio, sin embargo, la composición específica no varía ampliamente entre los sitios. Las comunidades de Cyanobacteria y Chlorophyta se ven afectadas por variables ambientales locales, mientras que las Rhodophyta están más influenciadas por variables espaciales.

Palabras clave: Algas macroscópicas, comunidades acuáticas, cuenca de México, ríos de montaña. 


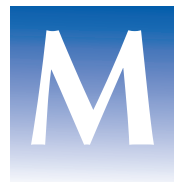

acroscopic algae communities (considering all algae with growth visible to the naked eye according to Sheath \& Cole 1992, and Phyla Cyanobacteria, Rhodophyta, Chlorophyta, and Heterokontophyta) play an important ecological role in the cycling of nutrients within lotic ecosystems (Sheath \& Burkholder 1985); they are at primary trophic level and are the largest producers of oxygen on the planet (Wehr \& Sheath 2003). Richness and species diversity depend on a number of environmental factors which in turn, are related to habitat heterogeneity at different temporal and spatial scales (Branco et al.2014). Species richness is a simple concept to interpret, because it is related to the total number of species present in a community and quantifies the diversity at the local level (Halffter-Salas \& Moreno-Ortega 2005). This parameter also describes an emerging property in the study of biological communities (i.e., diversity index) and is an important component in the calculation of the Shannon Wiener diversity, which helps to recognize changes in community structure (Pla 2006).

In general, major environmental variables that affect diversity in the benthic algae are temperature, pH, shading, substrate and current velocity (Burkholder 1996, Poulíčková et al. 2004). However, some variables are more relevant to particular taxons. For instance, the local environmental variables affecting Cyanobacteria (e.g., $\mathrm{pH}$, substrate size and nitrogen) are exclusive when compared to those of Chlorophyta (e.g., specific conductivity, incident light and current velocity). In the case of Rhodophyta, only spatial variables are known to influence their community composition (e.g., temperature). In contrast to the environmental variables, habitat heterogeneity is related to the morphological, reproductive and functional type of algae and the different ecological strategies that each species has developed to colonize streams (Borges \& Necchi 2006, Drakare \& Liess 2010). In this context, the asexual dispersal mechanisms (spores and fragmentation), sexual strategies (life-cycle types), and growth forms seem to be relevant factors explaining community structure in benthic algae. In species of Rhodophyta, the 'Chantransia' stage (or sporophyte phase) represents a common mode of propagation, particularly in the order Batrachospermales (Necchi \& Carmona-Jiménez 2002).

Algae communities respond differentially to ecological processes in their environment. However, is not obvious which environmental variables have more pronounced effects nor which species are more sensitive. Several studies of lotic ecosystems have provided important ecological information about the influence of environmental variables on the composition and distribution of macroscopic algae species in North America (Sheath \& Cole 1992) including the tropical and mountain streams of Mexico (Ramírez-Vázquez \& Cantoral-Uriza 2003, Bojorge-García et al.2010). We would expect that highest species diversity of macroscopic algae will occur during the cold-dry season, correlated with low temperature and oligothrophic water, characteristics of the mountain streams. Also, the distribution of each species will be related with heterogeneity of habitat and its dispersal strategies. Given these hypotheses, the goal of this work is to study the macroscopic algae communities by: i) assessing the species richness and diversity during the most contrasting seasons (cold-dry, rainy and warm-dry), ii) determining the environmental variables related to differences in the richness and diversity of the sampled sites, and iii) defining the species distribution.

\section{Materials and methods}

Study area. The Mexico Basin is in the central region of the country in an area between $19^{\circ} 02^{\prime}$ and $20^{\circ} 12^{\prime} \mathrm{N}$, and $98^{\circ} 28^{\prime}$ and $99^{\circ} 32^{\prime} \mathrm{W}$ (Figure 1). The climate is temperate, with torrential rains during summer that allow the establishment of conifer, oak and mixed forest (García 2004). Thirty-five sampled sites were investigated from 2012 to 2015 in the most contrasting seasons for three annual cycles: rainy season (June to November period), cold-dry season (December to February period) and warm-dry season (March to May period). Sites were pre-selected according to hydrological, land use and vegetation maps (INEGI 2013) and were georeferenced with GPS Etrex Garmin (Kansas, USA). Although an even sampling of the basin was desirable, there are uneven conditions preventing such strategy. For instance, urban land is more frequent in Northern and Eastern regions with no stream occurrence (Figure 1). Sampled sites included two contrasting categories. The first considered sites with streams distributed on conservation land (i.e., sites with restricted human activities and presence of native species in the riparian 


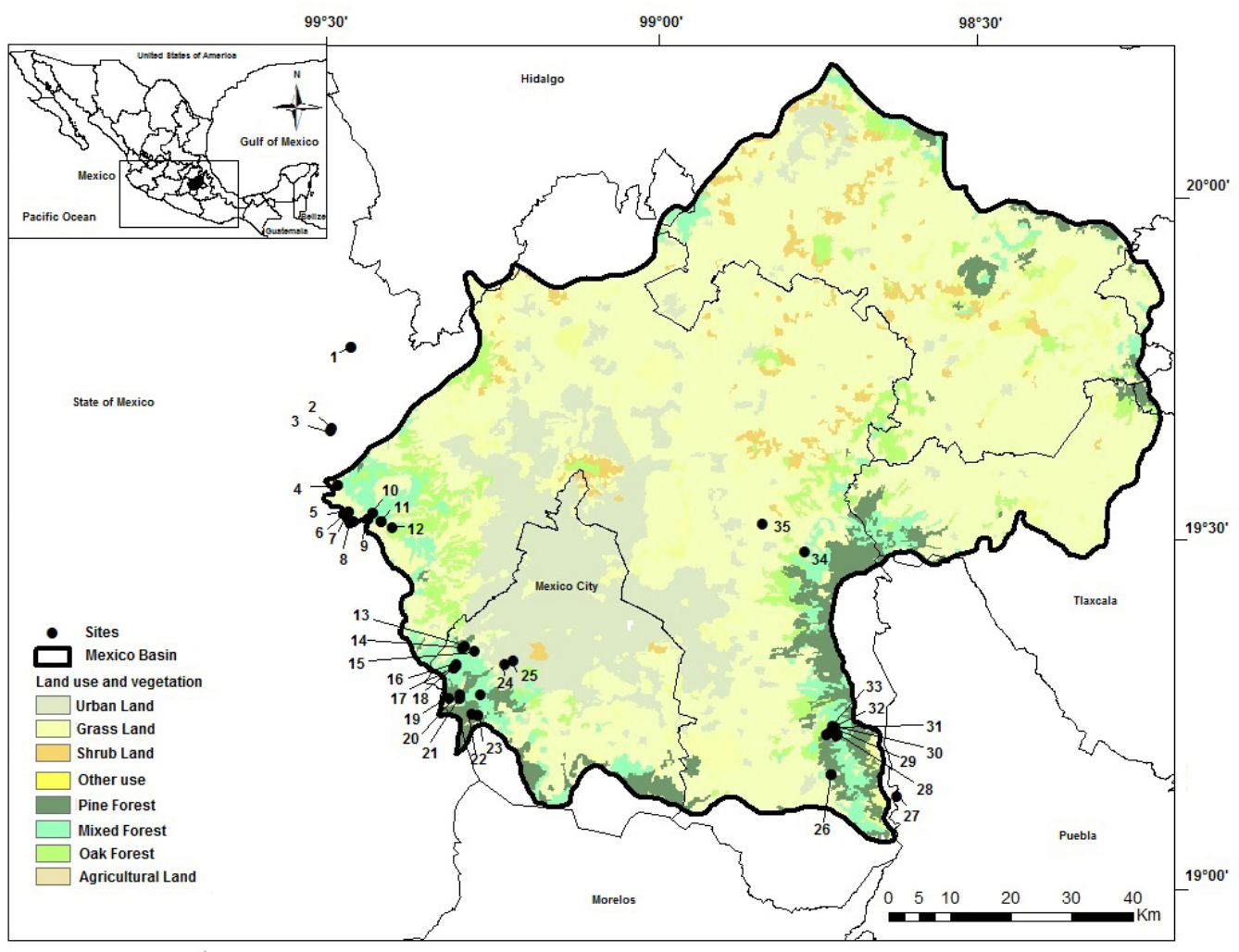

Figure 1. Sampling sites in the Mexico Basin. cold-dry season (CD), warm-dry season (WD) and rainy season (R). 1, El Llano (R); 2 , La Planta (R); 3, La Cabañita (R); 4, Las Palomas (R); 5, Los Organillos (R); 6, Nacimiento Presa Iturbide (R); 7, Truchero Don Álvaro (R); 8, Manantial Capoxi (R); 9, Río Capoxi (R); 10, Manantial San Pedro (R); 11, La Caldera (R); 12, Xopachi (R); 13, La Capilla (R); 14, Convento Desierto de los Leones (R); 15, Santa Rosa (R); 16, Chautitle Alto (CD); 17, Chautitle Cañada (CD); 18, Truchero Alto Magdalena (CD); 19, Manantial Eslava (CD); 20, Monte Alegre Bajo (WD); 21, Monte Alegre Alto (WD); 22, Valle de Monjas (CD); 23, Truchero Valle de Monjas (CD); 24, Confluencia Eslava-Magdalena (R); 25, Santa Teresa (R); 26, La Castañeda (R); 27, Apatlaco (WD); 28, Agua Dulce (R); 29, Inicio Canal San Rafael (R); 30, San Rafael Canal (WD); 31, San Rafael (WD); 32, Cascada Compañía (R); 33, Cosamala

(R); 34, Molino de Flores (R); 35, Santa Catarina (R).

zone) with some degree of environmental heterogeneity (i.e., areas of fast and slow currents, deep and shallow areas, variety of substrates and associated organisms, such as moss). These sites offer key ecological information to explain the relationship of different communities to the environment where they develop (Naiman et al. 2005). Furthermore, these sites serve as a reference to compare with the second category of sites, which were selected for being influenced by human activities, either urban or crop land, i.e., La Cabañita, La Planta, Santa Catarina, Molino de Flores, Confluencia Eslava-Magdalena and Santa Teresa (Figure 1).

Field work. Water temperature $\left({ }^{\circ} \mathrm{C}\right)$, hydrogen ion $(\mathrm{pH})$ and specific conductivity $\left(\mathrm{K}_{25}, \mu \mathrm{S} \mathrm{cm}^{-1}\right)$ were determined with a multiparametric probe HI991300 (Hach, Colorado, USA). Dissolved oxygen $\left(\mathrm{mg} \mathrm{l}^{-1}\right)$ was measured with an oxygen meter YSI-85 (Ohio, USA). Discharge $\left(\mathrm{Q}_{3}, \mathrm{~m}^{3}\right.$ $\left.\mathrm{s}^{-1}\right)$ was calculated according to Hauer \& Lamberti (1996). Water samples (200 ml) were collected on each site and filtered with Millipore (Darmstadt, Germany) nitrocellulose membranes $(0.45 \mu \mathrm{m}$ and $0.22 \mu \mathrm{m}$ pore diameter), deposited in sterilized containers and preserved in cool conditions until nutrient concentration tests were performed; this is, within the first 24 hours after sampling (APHA 2005). The environmental parameters and water samples were recorded at a depth of $20 \mathrm{~cm}$. Nitrogen concentration was determined as nitrite nitrogen $\left(\mathrm{NO}_{2}^{-}-\mathrm{N}\right)$, nitrate nitrogen $\left(\mathrm{NO}_{3}^{-} \mathrm{-}\right)$ and nitrogen ammonium $\left(\mathrm{NH}_{4}{ }^{+} \mathrm{N}\right)$; the sum of the three nitrogen forms determined the total concentration of dissolved inorganic nitrogen (DIN). Soluble reactive phosphorus (SRP) was determined as orthophosphate $\left(\mathrm{PO}_{4}^{-}-\mathrm{P}\right)$. All were determined with colorimetric reagents and a DR/3000 spectrophotometer (Hach, Colorado, USA), with two replicates for each sample (APHA 2005). 
The macroscopic algae morphological types were recognized according to Sheath \& Cole (1992): free filaments, mats, gelatinous colonies, and tissue-like forms. Each sampling site consisted of a randomly chosen stream segment, $10 \mathrm{~m}$ long. The segments were divided in five equal parts. On each of these segments, growths of algae were taken with the purpose of characterizing stream microhabitats. All samples were carefully collected from their base using a knife and deposited in containers with water from the same site. Containers were preserved in cold conditions until their examination. Relative abundance, based on the coverage percentage was recorded at each site, on each sampled season, with a circular sampling unit of $10 \mathrm{~cm}$ radius (Necchi et al. 1995, Bojorge-García et al. 2010). Microhabitat variables were measured in situ at the center of each sampling unit. Current velocity $\left(\mathrm{V}, \mathrm{m} \mathrm{s}^{-1}\right)$ and irradiance were measured as close to the alga as possible, using a Swoffer 3100 flow meter (Washington, USA), and a Li-Cor LI-1000 quantum meter (Nebraska, USA) with a flat subaquatic sensor of photosynthetically active radiation (PAR, $\mu \mathrm{M}$ photon $\mathrm{m}^{2} \mathrm{~s}^{-1}$ ), respectively. Substrate was determined as Boulder (> $250 \mathrm{~mm}$ diameter), pebbles ( $>80 \mathrm{~mm}$ diameter), gravel (5-15 mm diameter) or sand ( $<5 \mathrm{~mm}$ diameter). Also, we considered the aquatic vegetation as a type of substrate. For microscopic analyses and photographic documentation of cytological characters, semi-permanent slides for observations under microscope were made. Cross sections were made for the thalli of Paralemanea, Nostoc and Placoma. These sections were observed with an Olympus BX51 and SC35 microphotography system (Tokyo, Japan). Algae were identified to species level on the basis of various bibliographic resources (Carmona-Jiménez \& Necchi 2002, Wehr \& Sheath 2003, Komárek \& Anagnostidis 2005, Ramírez \& Carmona 2005, Carmona-Jiménez \& Vilaclara-Fatjó 2007, Komárek 2013). Algae were preserved in $3 \%$ formaldehyde after laboratory analyses and were made available to the Herbarium of the Faculty of Sciences (FCME), National Autonomous University of Mexico (UNAM), with an alphanumeric key.

Statistical analysis. The species richness was calculated as the total number of species per sampling site (Table 1). Species diversity was evaluated using the Shannon-Wiener Index $\left(H^{\prime} \log _{10}\right)$. To compare expected and observed species richness a rarefaction curve for whole studied area was calculated on EstimateS software v. 7.5 (Colwell 2005). The coefficient of variation (CV) was calculated to determine parameters of greater variability (Margalef 1988). In order to determine the relationships between algae species distribution and the environmental variables we employed a canonical correspondence analysis (CCA) performed in the program XLSTAT software v.2015.1 (Addinsoft 2013) and a Spearman test using SPSS software v. 17.0 (SPSS 2008). Among the advantages of using canonical correspondence analysis we can mention the detection of variation patterns in the data that are best explained by the environmental variables and the ability to indicate which are the most important relationships among species and recorded environmental parameters (Urban 2000, Rocha-Ramírez et al. 2006 Zuur et al. 2010).

\section{Results}

Taxonomic composition. Twenty-two species of benthic macroscopic algae were recognized; 12 species belonging to Chlorophyta (55\%), 6 to Cyanobacteria (27\%), 2 to Rhodophyta (9\%) and 2 to Xanthophyceae (Heterokontophyta) (9\%). Populations of Spirogyra spp. were allocated to two unnamed species on the basis of number of plastids and ecological abilities. Note that Draparnaldia mutabilis (Roth) Bory and Tetraspora gelatinosa (Vaucher) Desvaux are recorded here for the first time in the Basin of Mexico (Figure 3). Observed richness was similar to expected richness (Figure 2 ) with one to nine species per site $(3.3 \pm 1.8)$. In 29 sites $(83 \%)$ two or more species were present, while in six sites $(17 \%)$ a single species was observed (Table 1). Diversity indexes in each location varied between 0 and 2.6 (1.0 \pm 0.7$)$. The highest richness and diversity values $\left(S \geq 3 ; H^{\prime}\right.$ $\geq 1.0$ ) were found during the rainy and cold-dry seasons at 20 sites $(57 \%)$ at $\sim 3,000 \mathrm{~m}$ a.s.l. (Table 1). The most common morphological types were filamentous forms ( $40 \%$ ), followed by mats ( $35 \%)$ and gelatinous colonies (15\%); tissue-like forms were infrequent $(10 \%)$.

Environmental characterization. Environmental variables were appropriately characterized among sites and seasons: samples were made within a wide altitudinal gradient (from 2,345 


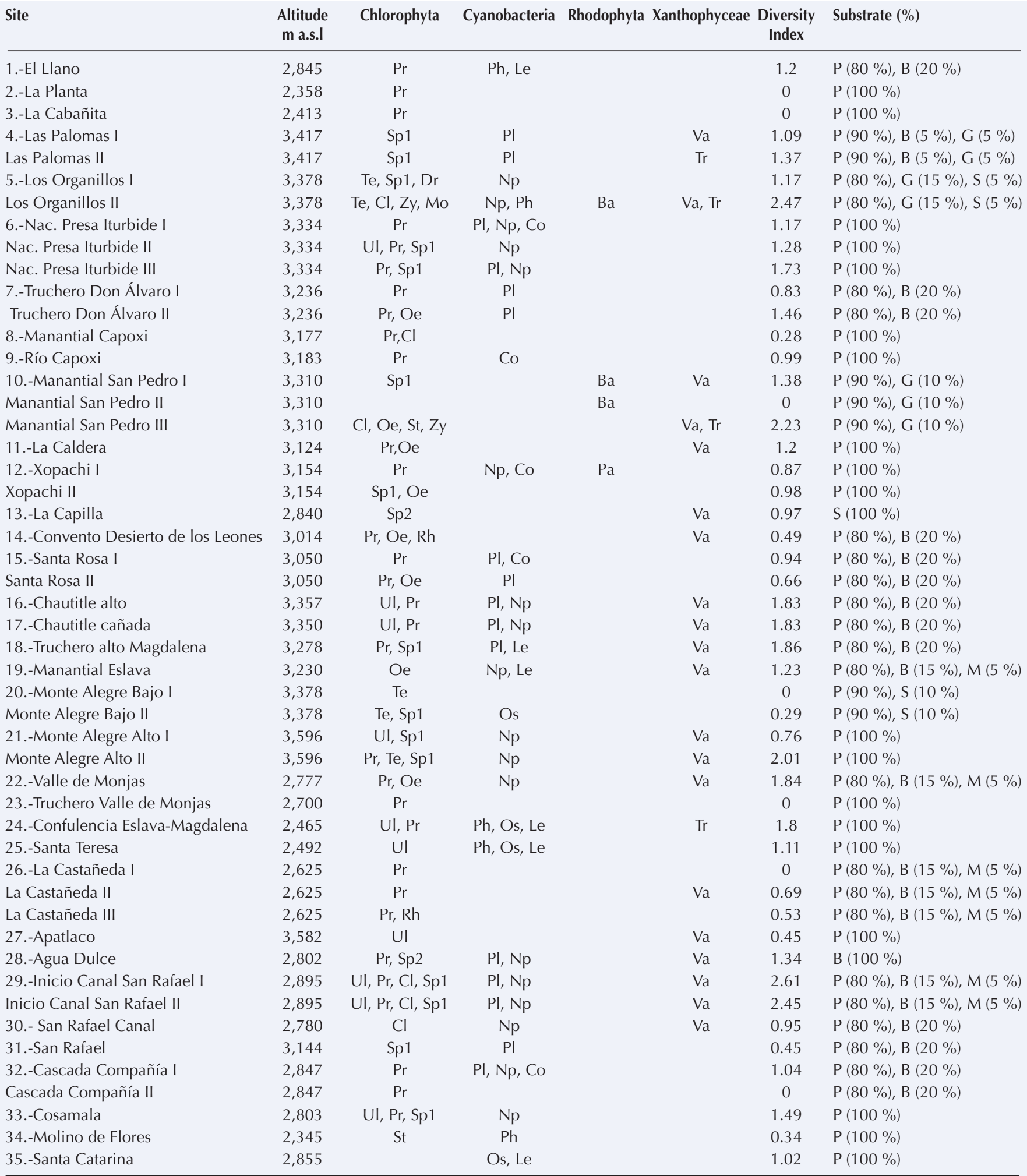

Chlorophyta: Cladophora glomerata (Cl), Draparnaldia mutabilis (Dr), Mougeotia sp. (Mo), Oedogonium sp. (Oe), Prasiola mexicana (Pr), Rhizoclonium sp. (Rh), Spirogyra sp.1 (Sp1), Spirogyra sp.2 (Sp2), Stigeoclonium sp. (St), Tetraspora gelatinosa (Te), Ulothrix sp. (UI), Zygnema sp. (Zy). Cyanobacteria: Coleodesmium wrangelii (Co), Leptolyngbya sp. (Le), Nostoc parmelioides (Np), Oscillatoria limosa (Os), Phormidium autumnale (Ph), Placoma regularis (PI). Rhodophyta: Batrachospermum gelatinosum (Ba), Paralemanea mexicana (Pa). Xanthophyceae (Heterokontophyta): Tribonema sp (Tr), Vaucheria bursata (Va). 
Figure 2. Species accumulation curve. Comparison of expected and observed macroscopic algae species in streams from the Basin of Mexico.
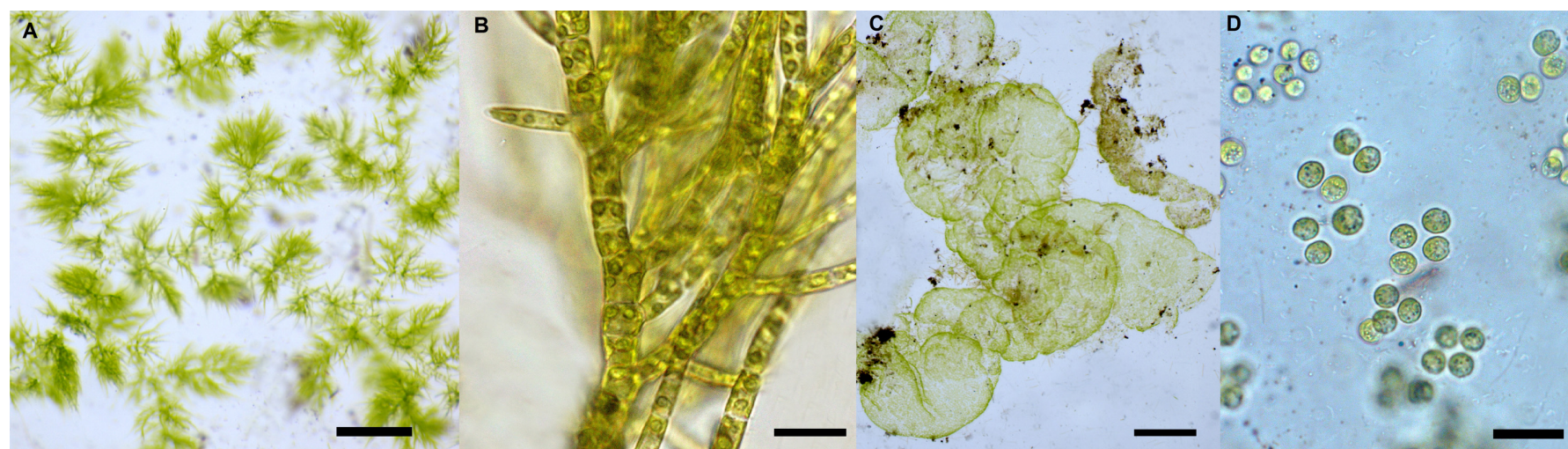

Figure 3. First records of Draparnaldia mutabilis (A, scale $1 \mathrm{~cm} ; \mathbf{B}$, scale $20 \mu \mathrm{m})$ and Tetraspora gelatinosa $(\mathbf{C}$, scale $1 \mathrm{~cm} ; \mathbf{D}$, scale 10 $\mu \mathrm{m})$ in the Basin of Mexico. 
Table 2. Environmental variables recorded in streams of the Basin of Mexico. DO, Dissolved oxygen; $\mathrm{T}^{\circ} \mathrm{C}$, temperature; $\mathrm{k} 25$, specific conductivity; SRP, Soluble reactive phosphorus; DIN, dissolved inorganic nitrogen; Q3, discharge; PAR, photosynthetically active radiation; V, current velocity.* Coefficient of variation $>10$.

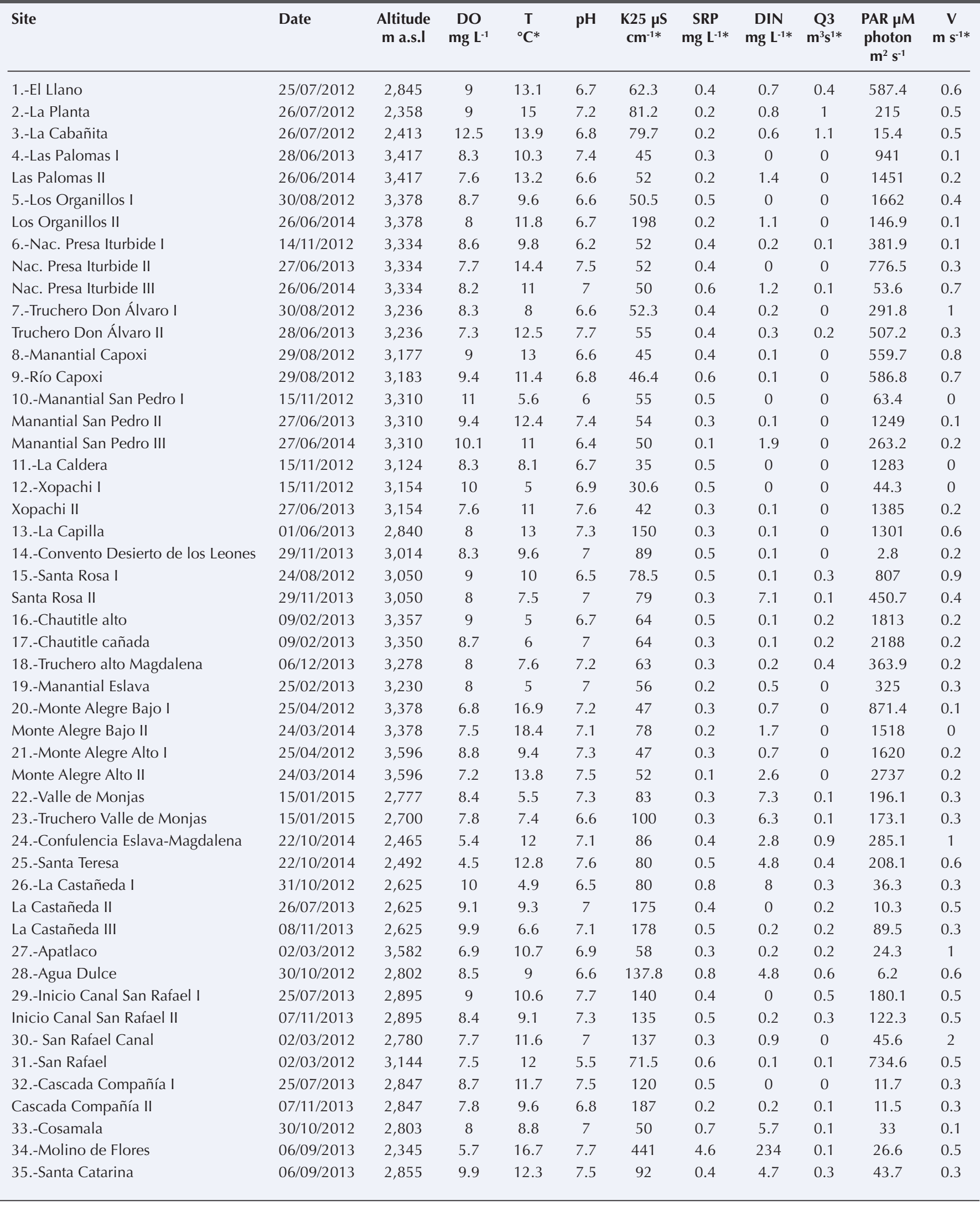


Table 3. Relationships among macroscopic algae distribution and environmental variables for the whole sample and each sampled site (Canonical correspondence analysis. Significance $p \leq 0.05$ ).

\begin{tabular}{|c|c|c|c|c|}
\hline & $\begin{array}{c}\text { Axis } 1 \\
41 \%\end{array}$ & $\begin{array}{c}\text { Axis } 2 \\
77 \%\end{array}$ & $\begin{array}{c}\text { Axis } 3 \\
90 \%\end{array}$ & $\begin{array}{c}\text { Axis } 4 \\
100 \%\end{array}$ \\
\hline \multicolumn{5}{|l|}{ Environmental variable } \\
\hline Temperature & 0.50 & & -0.65 & 0.52 \\
\hline Soluble reactive phosphorus & & -0.52 & -0.81 & \\
\hline Dissolved inorganic nitrogen & 0.51 & 0.54 & & -0.64 \\
\hline Discharge & 0.58 & -0.53 & 0.47 & 0.47 \\
\hline \multicolumn{5}{|l|}{ Species } \\
\hline Placoma regularis & & -1.06 & & \\
\hline Nostoc parmelioides & -0.48 & & & -1.04 \\
\hline Phormidium autumnale & 4.12 & 1.19 & -1.68 & -2.95 \\
\hline Oscillatoria limosa & 2.70 & 1.34 & 0.93 & \\
\hline Leptolyngbya sp. & 2.69 & & 1.97 & 1.08 \\
\hline Coleodesmium wrangelii & -1.04 & -1.06 & -3.24 & -0.95 \\
\hline Ulothrix sp. & & -1.28 & 0.77 & 0.85 \\
\hline Prasiola mexicana & & -0.60 & & \\
\hline Tetraspora gelatinosa & 0.86 & 2.50 & -1.93 & 1.07 \\
\hline Cladophora glomerata & & 0.60 & -0.60 & 1.22 \\
\hline Spirogyra sp. 1 & & 0.92 & -0.77 & \\
\hline Soirogyra sp.2 & & 0.82 & -1.59 & 1.05 \\
\hline Oedogonium sp. & -0.78 & & 1.61 & -1.43 \\
\hline Rhizoclonim sp. & & -1.22 & & 1.83 \\
\hline Draparnaldia mutabilis & -1.21 & -0.67 & -3.97 & -1.03 \\
\hline Stigeoclonium sp. & 0.73 & 2.87 & 0.65 & -2.93 \\
\hline Zygnema sp. & & 3.11 & 2.25 & \\
\hline Mougeotia sp. & & 2.68 & 0.79 & \\
\hline Batrachospermum gelatinosum & -1.64 & & & -1.12 \\
\hline Paralemanea mexicana & -2.54 & -1.99 & & -3.95 \\
\hline Vaucheria bursata & -0.47 & & 0.73 & \\
\hline Tribonema sp. & 1.03 & 1.78 & 2.25 & 1.16 \\
\hline \multicolumn{5}{|l|}{ Sampled site } \\
\hline San Rafael & & & -0.59 & \\
\hline Agua Dulce & 1.17 & -0.51 & & \\
\hline Inicio Canal San Rafael I & & -0.59 & & \\
\hline Cosamala & 0.51 & & & -0.57 \\
\hline Cascada Compañía I & & & -0.43 & \\
\hline La Castañeda I & & -1.27 & & \\
\hline Monte Alegre Alto I & & 1.14 & & \\
\hline Monte Alegre Bajo I & & 1.12 & & \\
\hline Manantial Eslava & -0.81 & & 0.53 & \\
\hline La Cabañita & 1.20 & -0.46 & 0.50 & 0.69 \\
\hline La Planta & 1.17 & & 0.43 & 0.66 \\
\hline El Llano & 0.58 & & & \\
\hline Santa Rosa I & & -0.44 & & \\
\hline La Capilla & & 0.42 & & \\
\hline Los Organillos II & & 0.75 & & \\
\hline Nacimiento Presa Iturbide II & & & -0.43 & \\
\hline Truchero Don Álvaro I & -0.48 & & & \\
\hline Las Palomas I & & 0.91 & & \\
\hline Manantial Capoxi & & & -0.47 & \\
\hline Río Capoxi & & & -0.57 & \\
\hline Manantial San Pedro II & -0.80 & -0.41 & & \\
\hline Xopachi I & -0.84 & -0.55 & & \\
\hline Chautitle Alto & -0.56 & -0.72 & & \\
\hline Chautitle Cañada & -0.44 & -0.48 & & \\
\hline Truchero Alto Magdalena & & -0.47 & & \\
\hline Santa Catarina & 0.89 & 0.45 & & \\
\hline Molino de Flores & 3.25 & & -1.99 & -2.12 \\
\hline Confluencia Eslava-Magdalena & 1.35 & & 0.41 & \\
\hline Santa Teresa & 1.05 & & & \\
\hline Valle de Monjas & & 0.55 & 0.73 & -0.63 \\
\hline Truchero Valle de Monjas & & 0.55 & 0.45 & -0.51 \\
\hline
\end{tabular}


between high DIN concentrations and the coverage percentage of P. autumnale, O. limosa, T. gelatinosa, Cladophora glomerata (Linnaeus) Kützing, Spirogyra sp. 1, Spirogyra sp. 2, Stigeoclonium sp., Zygnema sp., Mougeotia sp. and Tribonema sp., but a negative correlation between both high SRP concentrations $\left(\geq 0.7 \mathrm{mg} \mathrm{L}^{-1}\right)$ and higher discharge and the incidence of Placoma regularis P.A.Broady \& M.Ingerfeld, C. wrangelii, Ulothrix sp., Prasiola mexicana J. Agardh, Rhizoclonium sp., D. mutabilis and Paralemanea mexicana (Table 3).

The Spearman test showed a negative correlation between higher values of stream velocity $\left(>0.7 \mathrm{~ms}^{-1}\right)$ and the coverage percentage of Spirogyra sp. 1, T. gelatinosa and B. gelatinosum ( $Q=-0.33,-0.34 ; p=0.05)$. PAR is positively correlated with the coverage percentage of Spirogyra sp. $1(\varrho=0.33 ; p=0.05)$ and negatively with $T$. gelatinosa $(\varrho=-0.33 ; p=0.05)$. Some species have significant correlations with the coverage percentage of other species that may have similar environmental abilities. For instance, $P$. autumnale is positively correlated with $O$. limosa, Leptolyngbya sp., Mougeotia sp., and Tribonema sp. ( $\mathrm{Q}=0.38-0.47 ; p=0.01-0.05) ; C$. glomerata is positively correlated with Zygnema sp., Mougeotia sp. and Tribonema sp. $(\varrho=0.35$ $0.56 ; p=0.01-0.05)$; and Stigeoclonium sp. is correlated with Zygnema sp. $(\varrho=0.50 ; p=0.01)$ and Tribonema sp ( $\varrho=0.33-0.50 ; p=0.01-0.05)$. In contrast, Prasiola mexicana is negatively correlated with Spirogyra sp. $1, T$. gelatinos $a$ and B. gelatinosum ( $\varrho=-0.28$ to $-0.31 ; p=0.05$ ).

General distribution patterns. Species of Chlorophyta, Cyanobacteria and Xanthophyceae (Heterokontophyta) (Table 1) were found across a wide altitudinal gradient (from 2,345 to 3,596 m a.s.l), at sites with the highest species richness ( $>7$ species) and diversity ( $\left.>H^{\prime} 2.45\right)$. In contrast, Rhodophyta species (Table 1) were present in a narrower range of altitudes (from 3,100 to $3,400 \mathrm{~m}$ a.s.l) and were found in streams characterized by temperate water $\left(<12^{\circ} \mathrm{C}\right)$, moderate flow $\left(<0.7 \mathrm{~ms}^{-1}\right)$ and low light intensity $\left(<150 \mu \mathrm{M}\right.$ photon $\left.\mathrm{m}^{2} \mathrm{~s}^{-1}\right)$ (Table 2$)$. On the other hand the 'Chantransia' stage was observed in partially shaded streams and with different environmental conditions to the Rhodophyta.

\section{Discussion}

The greatest richness and diversity were observed at highest altitudes and during the rainy and cold-dry seasons. This pattern suggests that the communities of macroscopic algae are related to permanent streams and the constant temperate water, circumneutral $\mathrm{pH}$, low specific conductivity and high dissolved oxygen (Table 1 and 2). In addition, it is important to note that the composition of species does not vary widely among the sites sampled (Table 1). The species richness observed in the Basin of Mexico is similar to that previously reported for temperate streams in the central region of Mexico ( $S=3-8$ species in Ramírez-Vázquez et al. 2001, $S=2-7$ species in Bojorge-García et al.2010), with a relatively low species diversity when compared to other boreal streams in North America $\left(H^{\prime}=2.7-3.6\right.$ in Sheath \& Cole 1992).

Based on morphology and its relationship to the aquatic environmental strategies, we recognize two main groups of species in the Basin of Mexico. The first group comprises the most frequent and abundant species in the studied area: Prasiola mexicana, Vaucheria bursata, Placoma regularis and Nostoc parmelioides (Table 1). In these species, rhizoids develop in filamentous and tissue-like forms, and in colonial forms giving tolerance to the constant flow of water, discharge and high PAR (Sheath \& Hambrook 1990). In addition, these characteristics also confer anchorage for boulders and pebbles, by providing stability under the flow of water (Vieira \& Necchi 2002).

Likewise, in species of Cyanobacteria it is common that spores and resistant vegetative fragments facilitate dispersion and desiccation resistance (Drakare \& Liess 2010). These features may explain the dominance of species of these groups, since they may represent adaptations to environmental changes in streams. Although absence of sexual reproduction is common among species of Chlorophyta (Kristiansen 1996) and it is an important taxonomic character (Hoek et al. 1995), a significant change in photoperiod and water temperature can induce the formation of sexual structures (Bellis \& McLarty 1967, Lunning 1990). In this study sexual structures were observed in Spirogyra sp. 2, at locality La Capilla, which was characterized by significant changes in water discharge and PAR (Table 2). Wide geographical distribution observed in 
Cyanobacteria and Chlorophyta species suggests that distance is not a substantial barrier for spreading and successful asexual reproduction.

The second morphological group consists of Draparnaldia mutabilis, Tetraspora gelatinosa, Mougeotia sp. and Paralemanea mexicana, species that are less frequent and of narrower distribution (Wehr \& Sheath 2003, Carmona-Jiménez et al.2004, Table 1). These species were related to slow to high current velocities, or poorly to moderate illuminated areas in case of Rhodophyta (Bojorge-García et al. 2010). The fragile structure of the thallus makes them highly vulnerable to detachment by the water flow (Table 1 and 2). Furthermore, the scarcity of Paralemanea mexicana has been attributed to anthropogenic changes in the hydromorphology of streams and the short viability of its reproductive structures, which restricts their ability to propagate over long distances (Sheath 1984, Sheath et al. 1994), i.e., the disappearance of physical habitat limits their ability to establish elsewhere.

The occurrence of the 'Chantransia' stage in some streams responds to environmental changes and tolerance to stress (Necchi \& Carmona-Jiménez 2002). Nevertheless, the conductive conditions to the development of this stage are not well determined (Zucchi \& Necchi 2003). In this study the 'Chantransia' stage was common in partially shaded streams, less temperate and mesotrophic conditions, even when these conditions are not typical for species of Rhodophyta (Wehr \& Sheath 2003, Bojorge-García et al. 2010). Our results corroborate previous studies (Branco et al. 2009, Drakare \& Liess 2010, Branco et al. 2014) and also indicate that the community structure of organisms with low dispersal abilities is strongly influenced by spatial variables (e.g., current intensity).

Most of the streams sampled (63\%) showed low to moderate nutrient concentration in conservation areas, which are often close to springs. In contrast, eutrophic conditions are less frequent (37\% of all streams), which frequently occur in urban or crop areas with a potential contribution of pollutants in all the Basin of Mexico (Figure 1, Table 2). Species of Cyanobacteria, Chlorophyta and Xanthophyceae (Heterokontophyta) have a broad range of different ecological requirements that determine their dominance in many aquatic ecosystems. This ability results in a wider ecological and geographic distribution (Sheath \& Cole 1992, Bojorge-García et al. 2010). For example, in the most disturbed sites we have observed populations of Oscillatoria limosa, Leptolyngbya sp., Tetraspora gelatinosa and Tribonema sp., which are species tolerant to high DIN concentrations (Ramírez-Vázquez et al. 2001, Bojorge-García et al. 2010, Loza et al. 2013, Table 3). Likewise, Coleodesmium wrangelii, Placoma regularis, Ulothrix sp., Prasiola mexicana and Rhizoclonium sp. are tolerant to the presence of SRP, but they are not present when DIN is predominant (Table 3). Species of Cyanobacteria with heterocysts are diazotrophic, i.e., are mainly adapted to high SRP concentrations, and capable of fixing atmospheric nitrogen $\left(\mathrm{N}_{2}\right)$ to transform it into an assimilable form $\left(\mathrm{NH}_{4}^{+}\right)$(Bebout et al. 1993, Stal 1995). Thus, species such as Nostoc parmelioides are particularly successful on environments with low DIN concentrations, which explains its distribution on oligotrophic environments (e.g., Inicio Canal San Rafael and Xopachi sites). Moreover, according to the CCA and Spearman tests, some Chlorophyta, such as Cladophora glomerata and Prasiola mexicana, tolerate varying concentrations of nitrogen and phosphorus when the water current is constant (Table 3), similar to others streams in the Mexican Volcanic Belt (MVB) (Bojorge-García et al. 2010). On the other hand, the low flow of water and warmer temperatures can determine the presence of Mougeotia sp. in the streams (Novelo et al. 2007, Bojorge-García et al. 2010). Rhodophyta species are more frequent in sites with low ion concentration, firm substrate, low light intensity and temperate waters (Sheath 1984, Table 1 and 2). Batrachospermum gelatinosum is widely distributed in North America and Europe and is considered tolerant to a variety of physico-chemical conditions (Vis \& Sheath 1992, Eloranta \& Kwandrans 2004). In our study area we did not observe widespread distribution; here, its distribution was positively correlated with low flow, poor PAR and low ion concentration (Table 3), a combination of conditions that is uncommon in the streams studied. Paralemanea mexicana is endemic in the central region of Mexico; its abundance was lower than previously reported for this area (Carmona-Jiménez \& Necchi 2002). The frequent hydromorphological alteration, e.g., changes in trophic level and water discharge, could limit its development and may be the cause of its lower appearance possible in the region. However, the processes underlying this species abundance in particular are poorly understood. 
Our results suggest that stream macroscopic algae communities have a different structure among each Phylum, where local and spatial environmental variables explain differences in richness and distribution of species in this study area. This information helped us to better understand the response of each species to the wide spatial heterogeneity of the lotic environments and the relevance of environmental factors in their establishment and maintenance, which involves their life history, metabolic processes, life cycles and strategies of dispersion. The information provided in this work allowed us to unmask the ecological strategies that algae use to develop successfully within the streams. However, studies are still needed to explain in detail the ecological and physiological processes that affect the development of some species, mainly those among Chlorophyta and Rhodophyta. Such studies may support theories about the presence and distribution of macroscopic algae communities, e.g., Metacommunity theory (Brown et al. 2011, Branco et al. 2014).

In this respect, our results suggest that the specimens studied tend to distribute patterns similar to the algae metacommunities of Branco et al. (2014). In this regard, our results suggest that the specimens studied tend to exhibit dispersal patterns similar to those described previously for algae metacommunities e.g., Branco et al. (2014). Thus, we observed that the Cyanobacteria and Chlorophyta species with higher dispersal abilities (i.e., spores and resistant vegetative fragments, which facilitate dispersion and desiccation tolerance) are affected by local environmental variables (e.g., photosynthetically active radiation and substrate), whereas Rhodophyta, which have low dispersal abilities, are apparently influenced by spatial variables (e.g., temperature and current velocity). On the other hand, the ecological information provided in this study is relevant for the lotic environments of the central region of Mexico, which is threatened by landchange and pollution.

\section{Acknowledgments}

This work was supported by the Program for Research and Technological Innovation Projects (PAPIIT) IN211712 and IN220115, and Program of Support to Projects for the Innovation and Improvement of Teaching (PAPIME) PE208012. We are also grateful for the financial support offered by the National Council of Science and Technology (CONACYT) 631298 through the RRF Master's Scholarship, and the Graduate Program in Biological Sciences at UNAM. We also thank M. Cartajena and M. Bojorge for their comments on the manuscript, R. Salas-Lizana and A. Grant for linguistic revision and comments on the manuscript, R. Ortiz for help with the mapping.

\section{Literature Cited}

Addinsoft. 2013. XLSTAT for Windows. Version 2015.1. New York: XLSTAT Addinsoft. <https://www. xlstat.com/en/> (accessed November 12, 2016).

APHA (American Public Health Association), American Water Works Association and Water Environmental Federation. 2005. Standard methods for examination of water and wastewater. Port City Press. Washington, D.C.

Bebout BM, Fitzpatrick MW, Paerl HW. 1993. Identification of the sources of energy for nitrogen fixation and physiological characterization of nitrogen-fixing members of a marine microbial mat community. Applied and Environmental Microbiology 59: 1495-1503.

Bellis VJ, McLarty DA. 1967. Ecology of Cladophora glomerata (L.) Kutz. in southern Ontario. Journal of Phycology 3: 57-63. DOI: 10.1111/j.1529-8817.1967.tb04631.x

Bojorge-García M, Carmona J, Cartajena M, Beltrán Y, Cartajena M. 2010. Temporal and spatial distribution of macroalgal communities of mountain streams in Valle de Bravo Basin, central México. Hydrobiologia 641: 159-169. DOI 10.1007/s10750-009-0074-5

Borges FR, Necchi O. 2006. Patterns of spatial distribution in macroalgal communities from tropical lotic ecosystems. Revista Brasileira de Botânica 29: 669-680. DOI: 10.1590/S0100-84042006000400016

Branco CC, Bispo PC, Peres CK, Tonetto AF, Branco LHZ. 2014. The roles of environmental conditions and spatial factors in controlling stream macroalgal communities. Hydrobiologia 732: 123-132. DOI: 10.1007/s 10750-014-1852-2

Branco CCZ, Krupek RA, Peres CK. 2009. Distribution of stream macroalgal communities from the midwestern region of Paraná State, southern Brazil: importance of local-scale variation. Brazilian Archives of Biology and Technology 52: 379-386. DOI: 10.1590/S1516-89132009000200015. 
Brown BL, Swan CM, Auerbach DA, Campbell EH, Hitt NP, Maloney KO, Patrick C. 2011. Metacommunity theory as a multispecies, multiscale framework for studying the influence of river network structure on riverine communities and ecosystems. Journal of the North American Benthological Society 30: 310-327. DOI: 10.1899/10-129.1.

Burkholder JJ. 1996. Interactions of benthic algae with their substrata. In: Stevenson RJ, Bothwell ML, Lowe RL, eds. Algal Ecology. San Diego, California: Academic Press, 253-289.

Carmona-Jiménez J, Montejano G, Cantoral E. 2004. The distribution of Rhodophyta in streams from central Mexico. Archives für Hydrobiology Supplements 154/Algological Studies 114: 39-52. DOI: 10.1127/1864-1318/2004/0114-0039.

Carmona-Jiménez J, Necchi O. 2002. Taxonomy and distribution of Paralemanea (Lemaneaceae, Rhodophyta) in Central Mexico. Cryptogamie Algologie 23: 39-49. DOI: 10.1016/S0181-1568(02)85006-1

Carmona-Jiménez J, Vilaclara-Fatjó G. 2007. Survey and distribution of Batrachospermaceae (Rhodophyta) in high-altitude tropical streams from central Mexico. Cryptogamie Algologie 28: 271-282.

Colwell RK. 2005. EstimateS, Version 7.5: Statistical Estimation of Species Richness and Shared Species from Samples. <http://viceroy.eeb.uconn.edu/estimates/> (accessed November 12, 2016).

Dodds WK. 2003. Misuse of inorganic N and soluble reactive P concentrations to indicate nutrient status of surface Waters. Journal of North American Benthological Society 22: 171-181. DOI: $10.2307 / 1467990$.

Drakare S, Liess A. 2010. Local factors control the community composition of cyanobacteria in lakes while heterotrophic bacteria follow a neutral model. Freshwater Biology 55: 2447-2457. DOI: 10.1111/ j.1365-2427.2010.02473.x

Eloranta P, Kwandrans J. 2004. Indicator value of freshwater red algae in running waters for quality assessment. Oceanological and Hydrobiological Studies 33: 47-54. DOI: 10.5281/zenodo.454422

García E. 2004. Modificaciones al sistema de clasificación climática de Köppen. México: Instituto de Geografía. Universidad Nacional Autónoma de México.

Halffter-Salas G, Moreno-Ortega CE. 2005. Significado biológico de las diversidades alfa, beta y gamma. In: Halffter G, Soberón J, Koleff P, Melic A, eds. Sobre Diversidad Biológica: El Significado de las Diversidades Alfa, Beta y Gamma. Zaragoza, España. SEA, 5-18.

Hauer RF, Lamberti GA. 1996. Methods in Stream ecology. San Diego, California. Academic Press.

Hoek C, Mann DG, Jahns HM. 1995. Algae. An introduction to Phycology. Cambridge: Cambridge University Press.

INEGI. 2013. Cartas topográficas. Serie V, escala 1:50 000. Hojas E14A28 (Villa del Carbón), E14A49 (Villa Milpa Alta), E14B41 (Amecameca de Juárez), E14B31 (Chalco) y E14B21 (Texcoco de Mora).

Komárek J. 2013. Cyanoprokaryota. Freshwater Flora of Central Europe. In: Büdel B, Gärtner G, Krienitz L, Preisig HR, Schagerl M, eds. Süsswasserflora von Mitteleuropa. Berlin: Springer Spektrum.

Komárek J, Anagnostidis K. 2005. Cyanoprokaryota: Oscillatoriales. In: Büdel B, Gärtner G, Krienitz L, Preisig HR, Schagerl M, eds. Süsswasserflora von Mitteleuropa. Heidelberg: Elsevier Spektrum.

Kristiansen J. 1996. Dispersal of freshwater algae a review. Hydrobiologia 336: 151-157. DOI: 10.1007/ BF00010829

Loza V, Perona E, Carmona J, Mateo P. 2013. Phenotypic and genotypic characteristics of Phormidiumlike cyanobacteria inhabiting microbial mats are correlated with the trophic status of running waters. European Journal of Phycology 48: 235-252. DOI: 10.1080/09670262.2013.799715.

Lunning K. 1990. Seaweeds. Their Environment, Biogeography and Ecophysiology. New York: John Wiley and Sons.

Margalef R. 1988. Limnología. Barcelona, España. Omega.

Naiman RJ, Décamps H, Mc Clain ME. 2005. Riparia: Ecology, Conservation, and Management of Streamside Communities. Amsterdam: Elsevier Academic Press.

Necchi O, Branco LHZ, Branco CCZ. 1995. Comparison of three techniques for estimating periphyton abundance in bedrock streams. Archiv für Hydrobiologie Stuttgart 134: 393-402.

Necchi O, Carmona-Jiménez J. 2002. Somatic meiosis and development of juvenile gametophyte in members of Batrachospermales sensu lato (Rhodophyta). Phycologia 41: 340-347. DOI: 10.2216/i00318884-41-4-340.1

Novelo E, Tavera R, Ibarra C. 2007. Bacillariophyceae from Karstic Wetlands in Mexico. Bibliotheca Diatomologica, Berlin: J Cramer.

Pla L. 2006. Biodiversidad: inferencia basada en el índice de Shannon y la riqueza. Interciencia 31: 583590.

Pouličcková A, Hájková P, Křenková P, Hájek M. 2004. Distribution of diatoms and bryophytes on linear transects through spring fens. Nova Hedwigia 78: 411-424. DOI: 10.1127/0029-5035/2004/0078-0411

Ramírez-Vázquez M, Beltrán-Magos Y, Bojorge-García M, Carmona-Jiménez J. , Cantoral-Uriza EA, Valadez-Cruz F. 2001. Flora algal del Río La Magdalena, Distrito Federal, México. Boletín de la Sociedad Botánica de México 68: 51-73. DOI: 10.17129/botsci.1635 
Ramírez-Vázquez M, Cantoral-Uriza EA. 2003. Flora algal de ríos templados en la zona occidental de la cuenca del Valle de México. Anales del Instituto de Biología, Universidad Nacional Autónoma de México, Serie Botánica 74: 143-194.

Ramírez RR, Carmona J. 2005. The taxonomy and distribution of freshwater Prasiola (Prasiolales, Chlorophyta) from central México. Cryptogamie Algologie 26: 177-188.

Rocha-Ramírez A, Chávez-López R, Ramírez-Rojas A, Cházaro-Olvera S. 2006. Comunidades. Métodos de estudio. Facultad de Estudios Superiores Iztacala UNAM. México.

Sheath RG. 1984. The Biology of freshwater red algae. In: Round FE, Chapman DJ, eds. Progress in Phycological Research 3. Biopress Ltd. 89-157.

Sheath RG, Burkholder JM. 1985. Characteristics of softwater streams in Rhode Island. II. Composition and seasonal dynamics of macroalgal communities. Hydrobiologia 140: 183-191. DOI:10.1007/ BF00008730

Sheath RG, Cole KM. 1992. Biogeography of stream macroalgae in North America. Journal of Phycology 28: 448-460. DOI: 10.1111/j.0022-3646.1992.00448.x

Sheath RG, Hambrook JA. 1990. Freshwater ecology. In: Cole KM, Sheath RG, eds. Biology of the Red Algae, Cambridge: Cambridge University Press. 423-453.

Sheath RG, Vis LM, Cole KM. 1994. Distribution and systematics of Batrachospermum (Batrachospermales, Rhodophyta) in North America. 4. Section Virescentia. Journal of Phycology 30: 108-117. DOI: 10.1111/j.0022-3646.1994.00108.x

SPSS. 2008. SPSS Statistics for Windows, Version 17.0 Chicago: SPSS Inc. < http:// www.ibm.com/analytics/us/en/technology/spss/ > (accessed November 12, 2016).

Stal L. 1995. Tansley review $\mathrm{N}^{\circ} 84$. Physiological ecology of cyanobacteria in microbial mats and other communities. The New Phytologist 131: 1-32. DOI: 10.1111/j.1469-8137.1995.tb03051.x

Urban DL. 2000. Using model analysis to design monitoring programs for landscape management and impact assessment. Ecological Applications 10: 1820-1832. DOI: 10.1890/1051-0761(2000)010[1820: UMATDM]2.0.CO;2

Vieira J, Necchi O. 2002. Microhabitat and plant structure of Characeae (Chlorophyta) populations in streams from São Paulo State, southeaster Brazil. Criptogamie Algologie 23: 51-63.

Vis ML, Sheath RG. 1992. Systematics of the freshwater red algal family Lemaneaceae in North America. Phycologia 31: 164-179. DOI: 10.2216/i0031-8884-31-2-164.1

Wehr JD, Sheath RG. 2003. Freshwater Algae of North America. USA: Academic Press.

Zucchi MR, Necchi O. 2003. Blue-greenish acrochaetioid algae in freshwater habitats are "Chantransia" stages of Batrachospermales sensu lato (Rhodophyta). Criptogamie Algologie 24: 117-131.

Zuur AF, Ieno EN, Elphick CS. 2010. A protocol for data exploration to avoid common statistical problems. Methods in Ecology and Evolution 1: 3-14 DOI: 10.1111/j.2041-210X.2009.00001.x 